\title{
Physic-chemical characteristics and sensory evaluation of cakes with Nile tilapia
}

\section{(Oreochromis niloticus) waste flour}

Características físico-químicas e avaliação sensorial de bolos com farinha de resíduo de tillápia do

Nilo (Oreochromis niloticus)

Características físico-químicas y evaluación sensorial de tortas con residuos de harina de tilapia del

Nilo (Oreochromis niloticus)

Received: 06/02/2021 | Reviewed: 06/10/2021 | Accept: 06/15/2021 | Published: 06/29/2021

\author{
Anderson Lazzari \\ ORCID: https://orcid.org/0000-0003-4039-4772 \\ Universidade Estadual de Maringá, Brazil \\ E-mail: Anderson.lazzari29@gmail.com \\ Ingrid Caroline da Silva \\ ORCID: https://orcid.org/0000-0002-3606-0107 \\ Universidade Estadual de Maringá, Brazil \\ E-mail: ingrid_caroline95@hotmail.com \\ Gislaine Gonçalves Oliveira \\ ORCID: https://orcid.org/0000-0002-7819-3493 \\ Universidade Estadual de Maringá, Brazil \\ E-mail: gislaine_oliveira14@hotmail.com \\ Bianca de Oliveira Muller \\ ORCID: https://orcid.org/0000-0003-4192-3867 \\ Universidade Estadual de Maringá, Brazil \\ E-mail: biancamuller1996@gmail.com \\ Elisângela de Cesaro \\ ORCID: https://orcid.org/0000-0002-1113-9660 \\ Universidade Estadual de Maringá, Brazil \\ E-mail: eli.cesaro@hotmail.com \\ Bianka Rocha Saraiva \\ ORCID: https://orcid.org/0000-0002-6575-9857 \\ Universidade Estadual de Maringá, Brazil \\ E-mail: bianka_saraiva@hotmail.com \\ Ana Carolina Pelaes Vital \\ ORCID: https://orcid.org/0000-0002-6033-6898 \\ Universidade Estadual de Maringá, Brazil \\ E-mail: ana_carolv@hotmail.com \\ Maria Luiza Rodrigues de Souza \\ ORCID: https://orcid.org/0000-0001-5643-0841 \\ Universidade Estadual de Maringá, Brazil \\ E-mail: mlrsouza@uem.br \\ Paula Toshimi Matumoto-Pintro \\ ORCID: https://orcid.org/0000-0002-9182-5758 \\ Universidade Estadual de Maringá, Brazil \\ E-mail:ptmpintro@uem.br
}

\begin{abstract}
The fish processing industry generates a large amount of waste, that can be a nutrients source to the foods enrichment, such as cake that has low proteins, and consumed for different social classes. This study aimed to produced cakes with Nile tilapia (Orechromis niloticus) waste flour (NWF), formed by head, fins and the spine with meat remaining from filleting process, and evaluate its chemical and sensory properties. The formulations cakes with NWF obtained products with higher protein contents, essential fatty acids, and minerals, especially calcium and phosphorus, and lower car-bohydrates contents in relation to Control formulation (without NWF). The cakes with NWF had sensory acceptance (scores higher than 7.0 from 9.0 points) and purchase intention (scores higher than 3.8 from 5.0 points) and did not differ from the Control. The cakes with NWF can be a way to increase the supply of essential nutrients to the population through a popular and sensorial accepted product. This study showed that Nile tilapia waste flour (NWF) heads stands out a promising source for producing cake with high nutritional quality, positive economic potential, better physicochemical properties and, food industry solid waste reduction by used in food.
\end{abstract}

Keywords: Waste reuse; Fish flour; Fortification. 


\section{Resumo}

A indústria de processamento de pescado gera uma grande quantidade de resíduos, que podem ser uma fonte de nutrientes para o enriquecimento de alimentos, como bolos com baixo teor de proteínas, e consumidos por diferentes classes sociais. Este trabalho teve como objetivo produzir bolos com farinha de resíduo de tilápia do Nilo (Oreochromis niloticus) (NWF), formados por cabeça, barbatanas e espinha com carne re-manescente do processo de filetagem, e avaliar suas propriedades químicas e sensori-ais. As formulações de bolos com NWF obtiveram produtos com maiores teores de proteínas, ácidos graxos essenciais e minerais, principalmente cálcio e fósforo, e me-nores teores de carboidratos em relação à formulação Controle (sem NWF). Os bolos com NWF tiveram aceitação sensorial (escores superiores a 7,0 a 9,0 pontos) e inten-ção de compra (escores superiores a 3,8 a 5,0 pontos) e não diferiram do Controle. Os bolos com NWF podem ser uma forma de aumentar o fornecimento de nutrientes es-senciais à população através de um produto popular e sensorialmente aceito. Este estu-do evidenciou que as cabeças de farinha de tilápia do Nilo (NWF) destacam-se como fonte promissora para a produção de torta com alta qualidade nutricional, potencial econômico positivo, melhores propriedades físico-químicas e, redução de resíduos sólidos da indústria alimentícia por uso em alimentos.

Palavras-chave: Reaporveitamento de resíduos; Farinha de peixe; Fortificação.

\section{Resumen}

La industria de procesamiento de pescado genera una gran cantidad de desechos, que pueden ser una fuente de nutrientes para el enriquecimiento de los alimentos, como la torta que tiene bajas proteínas, y se consume por diferentes clases sociales. Este estu-dio tuvo como objetivo elaborar tortas con harina de desecho de tilapia del Nilo (Oreochromis niloticus) (NWF), formada por la cabeza, las aletas y el lomo con la carne remanente del proceso de fileteado, y evaluar sus propiedades químicas y sensoriales. Las formulaciones de tortas con NWF obtuvieron productos con mayor contenido de proteínas, ácidos grasos esenciales y minerales, especialmente calcio y fósforo, y me-nor contenido de carbohidratos en relación a la formulación Control (sin NWF). Los pasteles con NWF tuvieron aceptación sensorial (puntuaciones superiores a 7,0 desde 9,0 puntos) e intención de compra (puntuaciones superiores a 3,8 desde 5,0 puntos) y no difirieron del Control. Las tortas con NWF pueden ser una forma de incrementar el suministro de nutrientes esenciales a la población a través de un producto popular y aceptado sensorialmente. Este estudio mostró que las cabezas de harina de desecho de tilapia del Nilo (NWF) se destacan como una fuente prometedora para la producción de tortas con alta calidad nutricional, potencial económico positivo, mejores propieda-des fisicoquímicas y reducción de desechos sólidos de la industria alimentaria por su uso en alimentos.

Palabras clave: Reutilización de residuos; Harina de pescado; Fortificación.

\section{Introduction}

The global consumption of aquatic foods has increased recently, through the expansion of the human population and the growing preference for healthy sources of animal pro-tein. The expansion of fish farming in the world has been large and, Nile tilapia is con-sidered one of the most important species produced in pisciculture (FAO, 2018).

Fish processing industry generate and dispose important amounts waste solid materials during filleting or slicing operations. Study reported that, the use of these waste is de-ficient and needs of the development of practices that allow the better use, not only on to prepare animal feed and fertilizer (Moraes et al., 2021). These wastes are rich in organic and inorganic materials and can pollute natural resources and can be a patho-gens source harmful to health if released into the environment without prior treatment (Bastos et al., 2014). Instead of discarded, waste can be used in food to add value and make fish processing a more sustainable activity.

The fish waste has been explored in animal feed, due to their nutritional value and, consequently, due this nutritional potential, and economic interest, has also been ex-plored for food (Chapoutot et al., 2018). The fish meal can be used to increase nutri-tional value in food products, due to the large number of proteins and amino acids, can be used on inclusion of pasta, meat products and even sweets products (Stevanato, 2007; Goes et al., 2016; Kimura et al., 2017).

Bakery products are considerate one the most consumed food in the world, cakes stand out for their organoleptic characteristics that please consumers (Hera, Oliete \& Gómez, 2013). Cake is a poorly nutritious food and eaten in different social classes on the word. The characteristics technological of cakes are not compromised and possible with introduction of non-wheat flours (Hera et al., 2012). Studied new ingredients for cakes is important to increase their nutritional value and sensory acceptance, especial-ly its texture, that is an important characteristic. Food industry search new ingredients with 
adequate technological and nutritional properties. The objective of present study was added Nile tilapia waste flour in cakes, to improve its nutritional properties with sensory acceptance. And using a solid waste can be reduce environmental pollution.

\section{Methodology}

\subsection{Material and reagents}

Wholegrain oatmeal (10\% of total carbohydrates; $11 \%$ of protein; $6 \%$ of total fat and $14 \%$ of fibre), banana, eggs, raisin, chocolate (40\% cocoa), soy oil, cinnamon powder and baking powder were purchase from a local market. The Nile tilapia waste was from the Smartfish Company (Rolândia, PR, Brazil). Chloroform, methyl alcohol, sul-phuric acid, sodium hydroxide and hydrochloric acid were analytical grade.

\subsection{Nile tilapia waste}

\subsubsection{Flour preparation}

The waste (head, fins, and the spine with meat remaining from filleting process) from Nile tilapia (Oreochromis niloticus) processing were cleaned with proxitane $1512 ®(0.01 \%$ waste volume). The wastes were ground in an industrial meat grinder (CAF-10) and cooked under pressure for $60 \mathrm{~min}$ at $100{ }^{\circ} \mathrm{C}$ (Souza et al., 2017). After cook-ing, the waste was drained and pressed in a hydraulic press (10 ton for $5 \mathrm{~min}$ ) to re-move excess water. After, dried at $55{ }^{\circ} \mathrm{C}$ for $48 \mathrm{~h}$ and ground, sieved to 60 mesh and stored under refrigeration.

\subsubsection{Flour technological properties}

The technological properties of Nile tilapia waste flour (NWF) were evaluated to water absorption index (WAI) and water solubility index (WSI) (Anderson et al., 1969). Oil absorption capacity (OAC) (Lin et al., 1974). The results were expressed as percent-age.

\subsection{Cake's preparation}

Cakes were prepared with oat flour and different concentrations of Nile Tilapia waste flour (5\%, 10\% and 15\%). To prepare control cake, egg yolks, banana and soy oil were mixed for $2 \mathrm{~min}$, then added in a bowl with oat flour. Egg whites were mixed until snow point and added to the dough, then raisin and chocolate were crushed for $15 \mathrm{~s}$ also added to mixture and stirred until homogeneous. Cinnamon powder and baking powder were added. For other formulations (C5: cake with 5\% NWF; C10: cake with 10\% NWF and C15: cake with 15\% NWF), the cake was prepared with oat flour reduc-tion and added NWF to substitute. The cake was baked in silicone form for $20 \mathrm{~min}$ at $200{ }^{\circ} \mathrm{C}$ in a preheated oven $(10 \mathrm{~min})$.

\subsection{Physical-chemical properties}

\subsubsection{Chemical composition of NWF and cakes}

According to Pereira et al. (2018), a research was carried out using a quantitative and experimental methodology. Chemical composition was determined according to AOAC (2005) for moisture (method 930.15), crude protein by Kjeldahl method (nitrogen-to-protein conversion factor of 6.38), ash content (method 942.05), total fat (Bligh \& Dyer, 1959), crude fibre (method 978.10) and carbohydrates were determined by difference. Calcium (Ca) and Phosphorus (P) were determined by atomic absorption spectrometry (Silva et al., 2002). The $\mathrm{pH}$ was determined using a pH metre (Tecnopon, mPA-210) and caloric value (kcal/100 g) according to Souci et al. (2000). Water activity was determined by the method of dew point with Pawkit, Decagon ${ }^{\circledR}$ equipment. 


\subsubsection{Color evaluation}

The color was determined with a CR-400 digital colorimeter (Konica Minolta, light source D65) using the CIElab system. L* (luminosity), a*(-a green/+a red) and b* (-b blue/ +b yellow).

\subsection{Texture profile analysis}

Analysis of texture profile (TPA) was performed using a Brookfield Texture Analyzer CT-III (Brookfield Engineering Laboratories, Inc., Middleboro, EUA). A trigger force of $15 \mathrm{~g}$, speed of $2 \mathrm{~mm} / \mathrm{s}$ and compression distance of $7.5 \mathrm{~mm}$ were used with an acryl-ic circular probe of $38.1 \mathrm{~mm}$ diameter and $20 \mathrm{~mm}$ height. The hardness, chewiness and gumminess were analysed (AACC, 2000).

\subsection{Sensorial analysis}

Sensory analysis was about acceptability and purchase intention of samples. The Re-search Ethics Committee number was CAAE: 63777416.3.0000.0104. The cakes were coded with random three-digit numbers, and the acceptability was evaluated (Meil-gaard et al., 1999) with 107 adult consumers. The attributes of color, aroma, taste, tex-ture, and overall acceptance were evaluated by Consumers using a semi-structured 9-point hedonic scale $(1=$ highly disliked to $9=$ highly liked). Purchase intention of cakes was evaluated with the 5-point hedonic scale (5 - I will surely buy it; 1 - I won't buy it) (Peryam \& Pilgrim, 1957).

Microbiological analysis of total coliforms was performed to ensure hygiene and sani-tary quality of products manufactured for sensory analysis. Samples were assessed for the Most Probable Number (MPN) of coliforms at $35^{\circ} \mathrm{C}$ for $24 \mathrm{~h}$ (Vanderzant \& Splittstoesser, 1992).

\subsection{Statistical analyses}

Each experiment was performed in quintuplicate. Analysis of variance (ANOVA) was performed using the general linear model with SPSS (v.19.0) (IBM SPSS Statistics, SPSS Inc., Chicago, USA) for Windows. Mean and standard deviation were calculated for each variable. Differences were considered significant at $\mathrm{P}<0.05$ using the Tukey test. Sensory analysis data were evaluated by ANOVA and Tukey's test for the means comparison $(\mathrm{P}<0.05)$.

\section{Results and Discussion (can be separated or together)}

\subsection{Nile tilapia waste flour (NWF) characterization}

The results of chemical analysis of NWF are showed on Table 1, that was found NWF is abundant in crude protein and confirmed its potential to use as high protein ingredient for supplementation in cake. The NWF can contribute too for increase ash in food.

Carcasses of Nile Tilapia waste in this study, were placed in a hydraulic press to extract the natural fat present in fish, which explains the low-fat content in NWF. Overall, NWF is a poor source of fiber and carbohydrates. Chemical composition of NWF corresponds to the findings by Justen et al. (2017). 
Table 1. Nile tilapia waste flour (NWF) characterization.

\begin{tabular}{lr}
\hline & \multicolumn{1}{c}{ NWF } \\
\hline Moisture (\%) & $5.12 \pm 0.20$ \\
Crude protein (\%) & $63.23 \pm 0.34$ \\
Total fat (\%) & $3.60 \pm 0.33$ \\
Total carbohydrates $(\%)$ & $8.46 \pm 0.55$ \\
Crude fibre $(\%)$ & $0.63 \pm 0.26$ \\
Ash $(\%)$ & $20.37 \pm 0.17$ \\
CV ${ }^{2}(k c a l / 100 g)$ & $331.30 \pm 3.40$ \\
Calcium $(\%)$ & $1.11 \pm 0.07$ \\
Phosphorus $(\%)$ & $5.33 \pm 0.25$ \\
Aw & $0.43 \pm 0.01$ \\
\hline
\end{tabular}

Results are expressed as mean \pm standard deviation. ${ }^{1}$ Crude fibre was included in total carbohydrates. ${ }^{2} \mathrm{CV}$ is caloric value. Results were expressed in dry matter. Source: Authors.

\subsection{Cakes with NWF characterization}

The Aw value of control, C10 and C15 (Table 3) was a statistical difference $(p<0.05)$ showed an elevated water activity, corresponding with the WAI of the NWF (Table 2).

The structure formed in the cake may constrain the water molecules, this can block them out in the baking process and thus elevated aW of cakes is understood. Further, oat flour contains $\beta$-glucan which has elevated water detention capability (Silva et al., 2020). On chemical characterization of cakes with NWF (Table 3), it was found that the cakes (Control, C5, C10 and C15) showed statistical differences $(p<0.05)$ in all analysed parameters. The $\mathrm{pH}$ of cakes (Table 3 ) was close to neutral and remained unaffected by addition of NWF, remaining close to the $\mathrm{pH}$ of oat flour (Table 2). The decreased $(P<0.05)$ in caloric value of Control for $\mathrm{C} 15$ is related of decrease in carbohydrate content. The results mention that NWF is successfully used to reduce the calorie in cakes with best quality and nutrition value. Thus, it might be possible to produce cakes with low caloric value. Using NWF in formulation of foods allows processing products with low amount of fat and protecting human health against cardiovascular diseases.

Protein values ranged between $24.24 \%$ and $30.44 \%$ with sample C5 having the highest value. Proteins are important nutrients, a primary source of amino acids, which are the foundation of cellular protein (Adeleke \& Odedeji, 2010). NWF contained a high protein content (Table 1), inclusion of this ingredient in cakes was responsible for the increase in protein content. Fish is high in water content; equally protein has an elevated water holding capacity, corresponding with Aw value of cakes, previously mentioned.

Table 3 shows the color of the cakes, the luminosity $\mathrm{L}^{*}$ of the cakes had no significant difference. The $\mathrm{a}^{*}$ value of C15 was different of control, showing that high NWF content liquefied the ingredients and influenced the $\mathrm{a}^{*}$ value that showed darker and less deep red color. The $\mathrm{b}^{*}$ value of cakes increased $(P<0.05)$ with addition of NWF, corresponding with the high $b^{*}$ value of the NWF (Table 2). Maillard reaction are not attributed to the internal color changes, due to mild temperature reached by this part during the baking process (Helou et al., 2016). 
Table 2. Technological properties of Nile tilapia waste flour (NWF) and Oat flour.

\begin{tabular}{lcc}
\hline & NWF & Oat flour \\
\hline $\mathrm{pH}$ & $7.90 \pm 0.04^{\mathrm{a}}$ & $6.74 \pm 0.01^{\mathrm{b}}$ \\
WAI (\%) & $3.49 \pm 0.12^{\mathrm{a}}$ & $1.94 \pm 0.01^{\mathrm{b}}$ \\
WSI (\%) & $5.49 \pm 0.74^{\mathrm{a}}$ & $3.72 \pm 0.01^{\mathrm{b}}$ \\
OAC (\%) & $49.85 \pm 0.82^{\mathrm{a}}$ & $51.81 \pm 0.43^{\mathrm{a}}$ \\
$\mathrm{L}^{*}$ & $76.86 \pm 0.45^{\mathrm{b}}$ & $87.46 \pm 0.73^{\mathrm{a}}$ \\
$\mathrm{a}^{*}$ & $-0.21 \pm 0.07^{\mathrm{b}}$ & $0.43 \pm 0.04^{\mathrm{a}}$ \\
$\mathrm{b}^{*}$ & $15.69 \pm 0.20^{\mathrm{a}}$ & $11.12 \pm 0.11^{\mathrm{b}}$ \\
\hline
\end{tabular}

Results were expressed as mean \pm standard deviation. Different letters in the same line are significantly different $(P<$ 0.05) OAC, oil absorption capacity; WAI, water absorption index; WSI, water solubility index. Results were expressed in dry matter. Source: Authors.

Table 3. Physical-chemical analysis of cakes with Nile tilapia waste flour (NWF).

\begin{tabular}{|c|c|c|c|c|}
\hline & Control & C5 & C10 & C15 \\
\hline Moisture (\%) & $36.30 \pm 0.82^{\mathrm{b}}$ & $38.59 \pm 0.20^{\mathrm{a}}$ & $40.40 \pm 0.29^{\mathrm{a}}$ & $40.57 \pm 0.41^{\mathrm{a}}$ \\
\hline Crude protein (\%) & $24.24 \pm 1.11^{\mathrm{b}}$ & $30.44 \pm 0.27^{\mathrm{a}}$ & $28.87 \pm 0.91^{\mathrm{a}}$ & $29.05 \pm 0.85^{\mathrm{a}}$ \\
\hline Total fat $(\%)$ & $6.79 \pm 0.28^{b}$ & $6.46 \pm 0.51^{\mathrm{b}}$ & $6.99 \pm 0.56^{\mathrm{ab}}$ & $7.92 \pm 0.49^{\mathrm{a}}$ \\
\hline $\operatorname{Ash}(\%)$ & $5.69 \pm 0.08^{\mathrm{d}}$ & $6.55 \pm 0.09^{c}$ & $7.73 \pm 0.22^{\mathrm{b}}$ & $8.09 \pm 0.17^{\mathrm{a}}$ \\
\hline Total carbohydrates (\%) & $26.97 \pm 2.12^{\mathrm{a}}$ & $17.95 \pm 0.91^{\mathrm{b}}$ & $16.00 \pm 1.26^{\mathrm{bc}}$ & $14.36 \pm 1.08^{c}$ \\
\hline Crude fibre $^{1}(\%)$ & $3.41 \pm 0.32^{\mathrm{a}}$ & $3.43 \pm 0.21^{\mathrm{a}}$ & $2.61 \pm 0.14^{\mathrm{b}}$ & $3.00 \pm 0.11^{\mathrm{ab}}$ \\
\hline $\mathrm{CV}^{2}(\mathrm{kcal} / \mathbf{1 0 0 g})$ & $266.00 \pm 7.79^{a}$ & $251.72 \pm 1.68^{\mathrm{b}}$ & $242.40 \pm 3.33^{\mathrm{b}}$ & $244.98 \pm 4.18^{b}$ \\
\hline Calcium (Ca) (\%) & $0.32 \pm 0.02^{\mathrm{c}}$ & $0.48 \pm 0.01^{\mathrm{b}}$ & $0.60 \pm 0.02^{\mathrm{a}}$ & $0.65 \pm 0.08^{a}$ \\
\hline Phosphorus (P) (\%) & $0.23 \pm 0.02^{c}$ & $0.27 \pm 0.01^{\mathrm{b}}$ & $0.31 \pm 0.01^{\mathrm{a}}$ & $0.33 \pm 0.03^{\mathrm{a}}$ \\
\hline pH & $6.72 \pm 0.04^{\mathrm{bc}}$ & $6.63 \pm 0.04^{c}$ & $6.84 \pm 0.10^{\mathrm{a}}$ & $6.83 \pm 0.02^{\mathrm{ab}}$ \\
\hline Aw & $0.87 \pm 0.00^{\mathrm{b}}$ & $0.88 \pm 0.00^{\mathrm{ab}}$ & $0.89 \pm 0.00^{\mathrm{a}}$ & $0.89 \pm 0.01^{\mathrm{a}}$ \\
\hline \multicolumn{5}{|l|}{ Internal color of cakes } \\
\hline $\mathbf{L}^{*}$ & $46.79 \pm 0.81^{\mathrm{a}}$ & $47.47 \pm 0.65^{\mathrm{a}}$ & $48.06 \pm 0.73^{\mathrm{a}}$ & $47.08 \pm 0.68^{a}$ \\
\hline $\mathbf{a}^{*}$ & $5.75 \pm 0.13^{\mathrm{a}}$ & $5.62 \pm 0.17^{\mathrm{ab}}$ & $5.29 \pm 0.28^{\mathrm{bc}}$ & $5.09 \pm 0.29^{c}$ \\
\hline $\mathbf{b}^{*}$ & $11.22 \pm 0.31^{\mathrm{c}}$ & $13.28 \pm 0.09^{b}$ & $14.12 \pm 0.22^{\mathrm{a}}$ & $13.45 \pm 0.40^{b}$ \\
\hline
\end{tabular}

${ }^{1}$ Crude fibre was included in the total carbohydrates. ${ }^{2} \mathrm{CV}$ is caloric value. Results were expressed as mean \pm standard deviation. Different letters in the same line are significantly different $(P<0.05)$. Control: cake without NWF; C5: cake with 5\% NWF; C10: cake with $10 \%$ NWF; C15: cake with $15 \%$ NWF. Source: Authors.

\subsection{Cakes' texture}

The Control, C5 and C10 formulations did not presented difference for all parameters (Figure 1). Only C15 showed reduction $(P<0.05)$ in relation to the other formulations, showing that the addition of NWF up to $10 \%$ maintains the cakes texture profile, and from 15\% inclusion, the texture of the cake becomes softer, with the lower hardness, gumminess and chewinees. The lowest hardness of C15 (Figure 1), which used higher NWF content, may be related to reduction of interaction between macromolecules this caused the cake structure to rupture and weaken. However, the Control cake had a higher fiber content (Table 4) may be cause a reinforcement in the cake matrix which contributed to a more compact, firmer cake and less 
tendency to deformation. NWF and oat flour have a high oil absorption (Table 2). In food products, oil absorption (OAC) is an important functional property because it improves mouthfeel and flavor retention for providing adequate consistency properties, viscosity, and adhesion, improving texture quality (Rodriguez-Ambriz et al., 2005).

Figure 1. Texture profile analysis of cakes with Nile tilapia waste flour (NWF).

\section{Texture Profile}

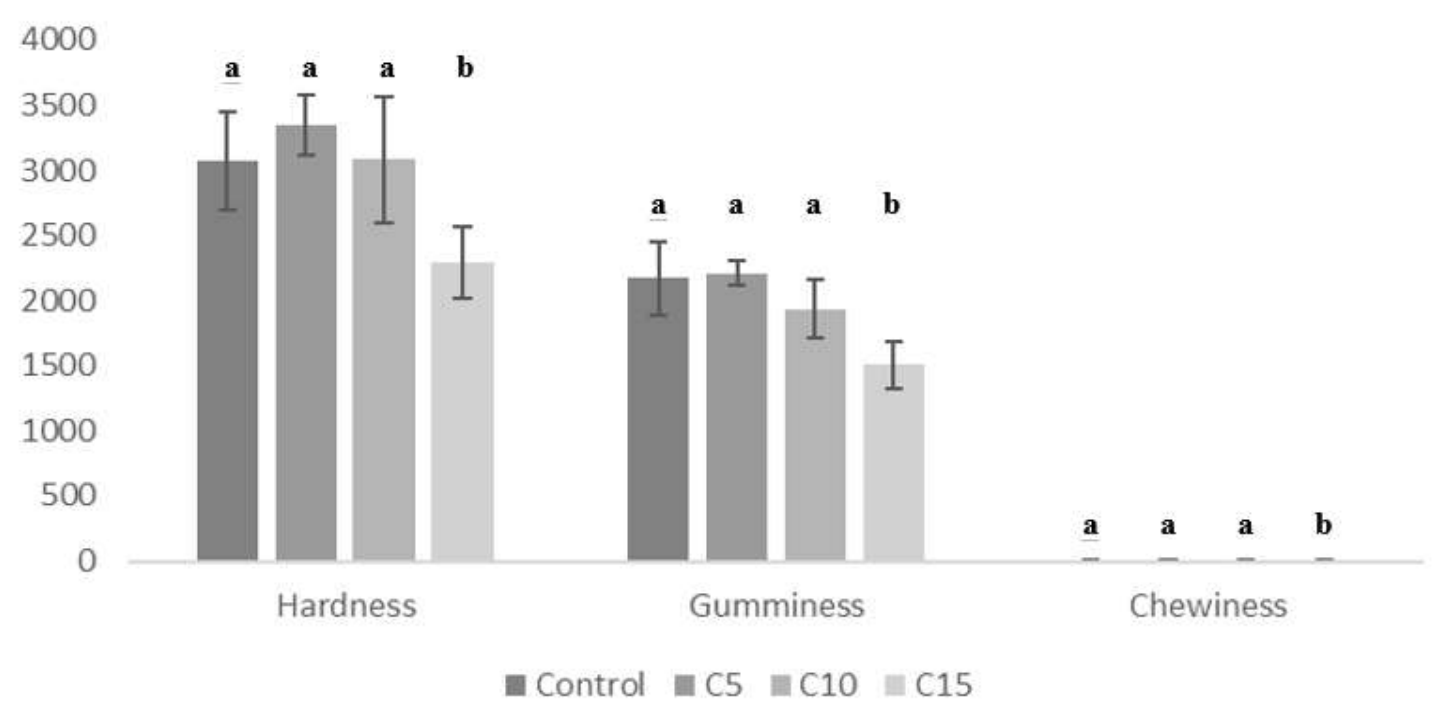

Control: cake without NWF; C5: cake with 5\% NWF; C10: cake with 10\% NWF; C15: cake with 15\% NWF. Different letters in the same parameter are significantly different $(P<0.05)$. Source: Authors.

\subsection{Sensory acceptability}

The profile of consumers who performed sensory analysis consisted of $63.55 \%$ women and $36.45 \%$ men. Most of the consumers were aged between 18 and 30 (83\%), while the consumers aged over 30 present $16 \%$ of consumers and the lowest representation of public. The microbiology of the cakes was evaluated to confirm the procedures. The most Probable Number of Coliforms at $35^{\circ} \mathrm{C}$ for all the cakes formulation were $<3\left(\mathrm{MNPg}^{-1}\right)$. This show that the cakes were prepared within the concepts of good handling and manufacturing practices.

Sensory analysis showed that the NWF inclusion did not have a significant effect on the cake's acceptability (Table 4) and for all attributes evaluated (color, aroma, taste, texture, and overall acceptance), the notes were higher than 7 ("like moderately"). Purchase intention showed no significant difference between all formulations and notes above 3.8, showing the acceptance by consumers and that NWF can be added in cakes to increase the nutritional value without affecting their sensorial characteristics.

Goes et al. (2016) included up to $15 \%$ of the dehydrated mixture (20\% of protein concentrate of salmon and $80 \%$ of tilapia) in spinach cake increases the contents of crude protein and mineral matter, besides reducing the carbohydrate content. However, based on the sensory results, it is recommended maximum inclusion level of $10 \%$ of the dehydrated mixture of fish in the spinach cake. Based on the sensory results, the authors recommended maximum inclusion level of $10 \%$ of the dehydrated mixture of fish in the spinach cake. In same study, inclusion of $15 \%$ did not achieve good results in the sensory analysis, because they used a dehydrated mix, containing marine fishmeal (salmon), which reduced the acceptability of the product. Flour from marine fish residues provides more accentuated characteristics of fish, needing more attention in its 
production to improve the flavour and aroma, mainly of the product where the flour will be included. On the other hand, this work included ingredients that aid in the organoleptic characteristics of the cake, such as bananas, raisins, chocolate, and cinnamon powder, thus obtaining such high marks for the evaluated parameters and up to $15 \%$ of NWF can be included.

Table 4. Sensory acceptability of cakes with Nile tilapia waste flour (NWF).

\begin{tabular}{lrrrr}
\hline & Control & C5 & C10 & C15 \\
\hline Color $^{1}$ & $7.33 \pm 0.09$ & $7.21 \pm 0.21$ & $7.61 \pm 0.19$ & $7.54 \pm 0.12$ \\
Aroma $^{1}$ & $7.52 \pm 0.03$ & $7.42 \pm 0.03$ & $7.47 \pm 0.02$ & $7.40 \pm 0.05$ \\
Taste $^{1}$ & $7.23 \pm 0.04$ & $7.32 \pm 0.13$ & $7.13 \pm 0.06$ & $7.03 \pm 0.16$ \\
Texture $^{1}$ & $7.34 \pm 0.02$ & $7.41 \pm 0.09$ & $7.17 \pm 0.15$ & $7.36 \pm 0.04$ \\
Overall acceptance $^{1}$ & $7.28 \pm 0.06$ & $7.46 \pm 0.12$ & $7.37 \pm 0.03$ & $7.25 \pm 0.09$ \\
\hline Purchase intention $^{2}$ & $3.85 \pm 0.02$ & $3.90 \pm 0.03$ & $3.88 \pm 0.01$ & $3.83 \pm 0.04$ \\
\hline
\end{tabular}

Results were expressed as mean \pm standard deviation. Different letters in the same line are significantly different $(P<0.05)$. Control: cake without NWF; C5: cake with 5\% NWF; C10: cake with 10\% NWF; C15: cake with $15 \%$ NWF. ${ }^{1}$ Hedonic scale between 1-9 points. ${ }^{2}$ Hedonic scale between 1-5 points. Source: Authors.

\section{Conclusion}

Nile tilapia (Oreochromis niloticus) waste flour NWF improve the nutritional value of cakes, with an increase in the content of proteins and minerals (calcium and phospho-rus) and a reduction in the caloric value. The addition of NWF did not affect the tex-ture of the cakes and was adequate to make cake softer with the highest level of substi-tution. Sensory analysis showed that NWF can be used without changing the flavour of the cakes. The results show that NWF can use as an ingredient to improve the physi-cal-chemical properties of cake, to nutritionally enrich cake and to reduction waste.

For future works, fish residues are new ingrediente options in production of bakety products, able to improve nutritional value of foods, shoul be further studied.

\section{Acknowledgments}

We thank Coordination of Improvement of Higher-Level Personnel Foundation (CAPES) for the scholarship.

\section{References}

AACC (2000). Approved methods of analysis. AACC international St, Paul, MN.

AOAC. Official methods of analysis of the AOAC (2005). In: AOAC-Association of Official Analytical Chemists, (18th ed,). AOAC.

Adeleke, R. O., \& Odedeji, J. O. (2010). Functional Properties of Wheat and Sweet Potato Flour Blends. Pakistan Journal of Nutrition, 9: 535 - 538.

Anderson, R. A., Conway, H. F., Pfeifer, V. F, \& Griffin, E. L. (1969). Roll and extrusion-cooking of grain sorghum grits. Cereal Science Today, 14: 372376.

Bastos, R. K. X., Cabral, V. A. L., Rios, E. N., \& Combatt, M. P. M. (2014). Further contributions to nitrogen removal modelling in waste stabilization ponds. Water Science \& Technology, 70: 1897-1906.

Bligh, E. G., \& Dyer, W. J. (1959). A rapid method of total lipid extraction and purification. Canadian Journal of Biochemistry and Physiology, 37 : $911-917$.

Chapoutot, P., Rouillé, B., Sauvant, D., \& Renaud, B. (2018). Les coproduits de l'industrie agro-alimentaire: des ressources alimentaires de qualité à ne pas négliger. Dossier: Ressources alimentaires pour les animaux d'élevage, 31: 201-220.

De La Hera, E., Martinez, M., Oliete, B., \& Gomez, M. (2012). Influence of flour particle size on quality of gluten-free rice cakes. Food and Bioprocess Technology, 6: 2280-2288.

De La Hera, E., Oliete, B., \& Gómez, M. (2013). Batter Characteristics and Quality of Cakes made with Wheat-Oat Flours Blends. Journal of Food Quality, 36 (2): 146-153. 
Research, Society and Development, v. 10, n. 7, e47210716725, 2021

(CC BY 4.0) | ISSN 2525-3409 | DOI: http://dx.doi.org/10.33448/rsd-v10i7.16725

FAO (2018). The state of World Fisheries and Aquaculture 2018 - Meeting the Sustainable Development Goals. Licence, Rome. CC BY-NC-AS 3.0 IGO.

Goes, E. S. R., Souza, M. L. R., Kimura, K. S., Franco, M. C., Verdi, R., \& Mikcha, J. M. G. (2016). Inclusion of dehydrated mixture made of salmon and tilapia carcass in spinach cakes. Acta Scientiarum Technology, 38: 241-246.

Helou, C., Jacolot, P., Niquet-Léridon, C., Gadonna-Widehem, P., \& Tessier, F. J. (2016). Maillard reaction in bread: A novel semi-quantitative method for evaluating melanoidins in bread. Food Chemistry, 190: 904-911.

Justen, A. P., Souza, M. L. R., Monteiro, A. R. G., Mikcha, J. M. G., Gasparino, E., Delbem, A. B., De Carvalho, M. R. B., \& Del Vesco, A. P. (2017). Preparation of Extruded Snacks with Flavored Flour Obtained from the Carcasses of Nile Tilapia: Physicochemical, Sensory, and Microbiological Analysis. Journal of Aquatic Food Product Technology, 26: 258-266.

Moraes, P. S., Engelmann, J. I., Igansi, A. V., Jr Cadaval, T. R. S., \& Pinto, L. A. A. (2021). Nile tilápia industrialization waste: Evaluation of the yield, quality and cost of the biodiesel production process. Journal of Cleaner Production, 287: 125041.

Kimura, K. S., Souza, M. L. R., Verdi, R., Coradini, M. F., Mikcha, J. M. G., \& Goes, E. S. R. (2017). Nutritional, microbiological, and sensorial characteristics of alfajor prepared with dehydrated mixture of salmon and tilapia. Acta Scientiarum. Technology, 39: 111-117.

Lin, M. J. Y., Humbert, E. S., \& Sosulski, F. W. (1974). Certain functional properties of sunflower meal products. Journal of Food Science, 39: 368-370.

Meilgaard, M., Civille, G.V., \& Carr, B. T. (1999). Sensory Evaluation Techniques. CRC Press.

Pereira, A. S., Shitsuka, D. M., Parreira, F. J., \& Shitsuka, R. (2018). Metodologia da pesquisa científica. UFSM. https://repositorio.ufsm.br/bitstream/handl e/1/1 5824/Lic_Computacao_Metodologia-Pesquisa-Cientifica.pdf?sequence=1

Peryam, D. R., \& Pilgrim, F. J. (1957). Hedonic Scale of Measuring Food Preferences. Food Technology, 11: 9-14.

Rodríguez-Ambriz, S. L., Martínez-Hernández, G., González, J. E. C., \& Trujillo, J. P. P. (2005). Composition and functional properties of Lupinus campestris protein isolates. Plants Foods for Human Nutrition, 60: 99- 107.

Silva, D. J., \& Queiroz, A. C. (2002). Análise de alimentos: métodos químicos e biológicos. (3rd ed). UFV.

Silva, A. S., Correa, L. G., Kanai, R. S. S., \& Shirai, M. A. (2020). Effect of sugarcane bagasse addition on physical, chemical, and sensory properties of oat flour and banana cake. Journal of Texture Studies, 1-7.

Souci, S., Fachman, W., \& Kraut, H. (2000). Foods composition and nutrition tables (6th ed.). Washington, DC. Medpharm Scientific Publishers.

Souza, M. L. R., Yoshida, G. M., Campelo, D. A., Moura, L. B., Xavier, T. O., \& Goes, E. S. R. (2017) Formulation of fish waste meal for human nutrition. Acta Scientiarum Technology, 39: 525-531.

Stevanato, F. (2007). Avaliação química e sensorial da farinha de resíduo de tilápias na forma de sopa. Ciência e Tecnologia de Alimentos, 27 : 567-571.

Vanderzant, C., \& Splittstoesser, D. F. (1992). Compendium of methods for the microbiological examination of foods. (3rd ed.). American Public Health Association. 